\title{
Germination of tomatoes under PEG-induced drought stress
}

\author{
Milka Brdar Jokanović · Jasmina Zdravković
}

\begin{abstract}
Summary: The aims of this study were: to assess the effects of drought stress on germination percentage, germination energy and number of days to complete germination in fifteen tomato populations; to distinguish the treatment that is the most suitable for classifying the tomatoes for their response to early-imposed drought; as well as to distinguish populations which could be used for breeding tolerant varieties. The experiment included control germination assay (distilled water) and the increasing $(4,8$, and $12 \%, \mathrm{w} / \mathrm{v}$ ) polyethylene glycol (PEG) treatments. Both germination percentage and energy considerably decreased with the increasing PEG treatments, while the observed average increase in the number of days required to complete germination remained statistically insignificant. The differences in germination among the populations were most pronounced in $12 \%$ PEG treatment, which is therefore recommended for further research. Several populations are indicated as tolerant; however, tomato drought tolerance exhibited as early as at the germination stage does not necessarily indicate the tolerance in later phases of plant development. The population 105 is recommended for breeding drought tolerant varieties.
\end{abstract}

Keywords: drought tolerance, germination, Lycopersicon esculentum Mill., polyethylene glycol, tomatoes

\section{Introduction}

With approximately 4.7 million ha of harvested area, annual production of 156.6 million tones and average yield of $33.4 \mathrm{t} / \mathrm{ha}$ (2009-2012 period), tomato (Lycopersicon esculentum Mill.) represents one of the world's most important vegetable species. In Serbia, tomatoes are among major crops and occupy about 20,000 ha, with annual production of 180-185 tones. In comparison to the officially reported average yields that usually do not exceed 9-10 t/ha, Serbian cultivars and hybrids are of the far greater potential. The discrepancies between actual and potential yields are mostly due to the comparatively low investments in the growing technology.

Water shortage is one of the most important causes of yield losses in world's agricultural production; therefore the appropriate irrigation represents one of the main agro-technical procedures required to achieve good crop yields. Accordingly, about $20 \%$ of the world's cultivated

M. Brdar-Jokanović*

Institute of Field and Vegetable Crops, 30 Maksima Gorkog, 21000 Novi Sad, Serbia

e-mail: milka.brdar@ifvens.ns.ac.rs

J. Zdravković

Institute for Vegetable Crops, 71 Karađordeva, 11420 Smederevska Palanka, Serbia area is actually irrigated, contributing to $40 \%$ of total food production. The irrigated area is not uniformly distributed, primarily due to the ability of the region to invest in irrigation systems and the frequency and severity of the occurring droughts. Vegetables are the second most irrigated crops $(10 \%)$, following only cereals $(60 \%)$, primarily rice. However, in Serbia only $0.7 \%$ of the utilized agricultural area $(1.1 \%$ of all arable fields and gardens) is actually irrigated, with the majority of the area being localized in the Vojvodina region. Tomato is known as a water-demanding crop, which is especially true for modern varieties. Although tomato has high water requirements throughout the whole life cycle, drought tolerance of the specific genotype may vary with the developmental stage. Ideal genotype would express satisfactory level of tolerance at as many as possible life stages and therefore be utilized for breeding drought tolerant cultivars and hybrids of high yield and quality (Foolad 2007, Takač et al. 2007, Ashraf 2010, Zdravković et al. 2010, Stat. Yearb. Serb. 2012, 2013, Shamim et al 2014, AQUASTAT 2015, FAO 2015, RZS 2015).

Acknowledgements: This work was supported by the Ministry of Education, Science and Technological Development of the Republic of Serbia (Research Grants: TR-31005 and TR-31059). 
This study was conducted in order to assess the effects of PEG-induced drought on germination in fifteen tomato populations; to distinguish the treatment that is most suitable for classifying the tomatoes on the basis of tolerance to early-imposed drought; as well as to distinguish populations which could be used for breeding tolerant varieties.

\section{Material and Methods}

The material used in this study consisted of fifteen tomato (Lycopersicon esculentum Mill.) populations chosen from the collection of Serbian local populations, maintained at the Institute for Vegetable Crops in Smederevska Palanka. The populations (designated with numbers 101, 104-107, 109-116, 122 and 138) are potential starting material for breeding of new tomato cultivars and hybrids, and have previously been tested for drought tolerance at the stage of intensive vegetative growth (Zdravković et al. 2013, Brdar-Jokanović et al. 2014a, 2014b). The trial was conducted at the Institute of Field and Vegetable Crops, Novi Sad.

The assay was performed at the germination stage, by simulating drought stress with polyethylene glycol (PEG) 6000 which lowers the osmotic potential of the solution. Tomato seeds were germinated in Petri dishes, on the filter paper moistened with distilled water (control), and 4, 8 and $12 \%$ PEG solutions (treatments). The solutions had the osmotic pressure of $-0.36,-1.03$ and -2.01 bars, respectively (at $25^{\circ} \mathrm{C}$, Michel \& Kaufmann 1973). The dishes were placed in germination chamber for fourteen days, in dark and at $25^{\circ} \mathrm{C}$. All variants included three replications, with 50 seeds per each. The first germination reading was performed three days after setting the experiment and continued on the daily basis. Germination percentage, germination energy and the number of days to complete germination were noted. Germination energy was expressed as the percentage of the germinated seeds, noted five days after the beginning of the experiment.

Mean values, coefficients of variation, and Spearman's coefficients of rank correlation were calculated for the analyzed parameters. Stress tolerance indices (Fernandez 1992) were calculated for germination percentage and energy of the particular populations as follows:

$$
S T I=(G E 12 \times G E 0) / \overline{G E 0}^{2},
$$

GE12 and GE0 - germination energy of the population in $12 \%$ PEG treatment and in control, respectively, $\overline{G E 0}$ - germination energy in control, average for all populations.
The data were processed by analysis of variance, and the means were compared using LSD test. Statistica 12.0 (StatSoft, Dell Inc., USA; University of Novi Sad License) software package was used for the calculation and graphing.

\section{Results and Discussion}

Polyethylene glycol (PEG) treatments are widely used to induce drought stress in plants, especially when it comes to early stages of their life cycle. However, the concentrations of the PEG solution reported as informative for distinguishing tolerant and sensitive genotypes vary. This is probably due to the characteristics of the material analyzed in such studies (number of genotypes, their divergence, origin, etc.), the phase of plant development in which the treatment was applied, as well as the duration and the type of the experiment (in vitro, hydroponic, pot, etc.). Accordingly, PEG concentrations varying from as low as $4 \%$ to even $12.5 \%$ were reported as suitable for screening tomatoes for drought tolerance at germination and seedling stage (Ragab et al. 2007, Ghebremariam et al. 2013, George et al. 2013). Therefore, it is useful to optimize the PEG concentration before setting any particular larger experiment. The second important prerequisite for implying the procedure for tomato drought tolerance screening would be the choice of the tomato trait exhibiting the adequate response to the treatments.

As for our research, the average effects of the imposed PEG treatments on the germination percentage, germination energy and the number of days to complete germination are shown in Table 1, while Figure 1 represents the response to PEG at the population level. Significant differences have been found among both PEG treatments and tomato populations in terms of germination percentage and energy, with population $\times$ treatment interactions being also significant ( $p<0.00$, not shown). Although the number of days to complete germination considerably varied among the populations (from 3.3 to 9.7 days in the control, for example), the effects of the increasing treatments were often inconsistent within the particular population and therefore remained insignificant on average. Hence this parameter is not further discussed as selection criterion for PEG simulated tomato drought tolerance.

PEG-simulated drought stress decreased the value of both germination percentage and energy in similar, approximately exponential manner. The weakest PEG treatment reduced germination percentage and energy for 3.9 and $3.1 \%$, respectively, which is not enough informative for ranging the populations in terms of drought tolerance. 
a)

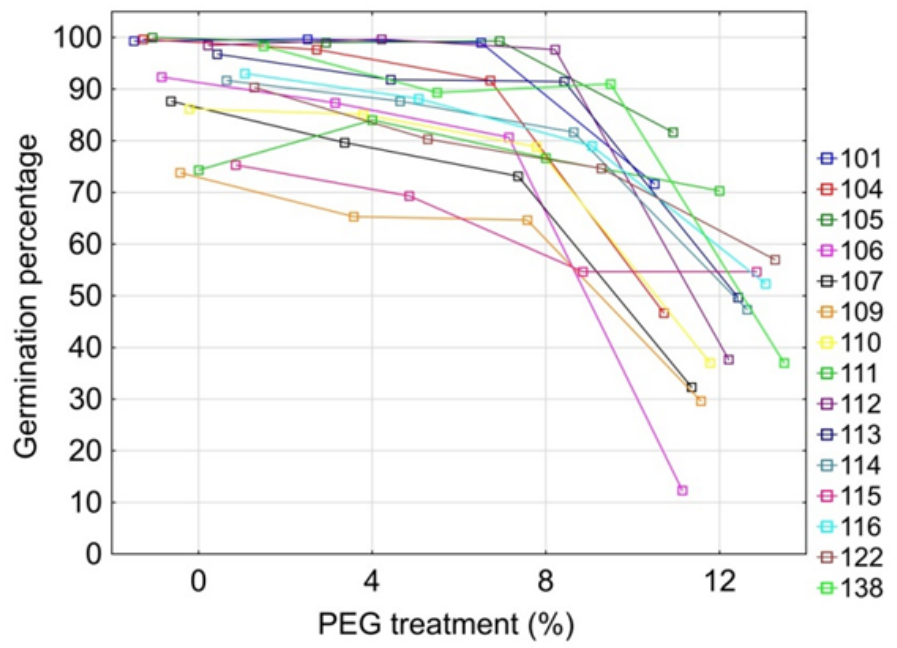

b)

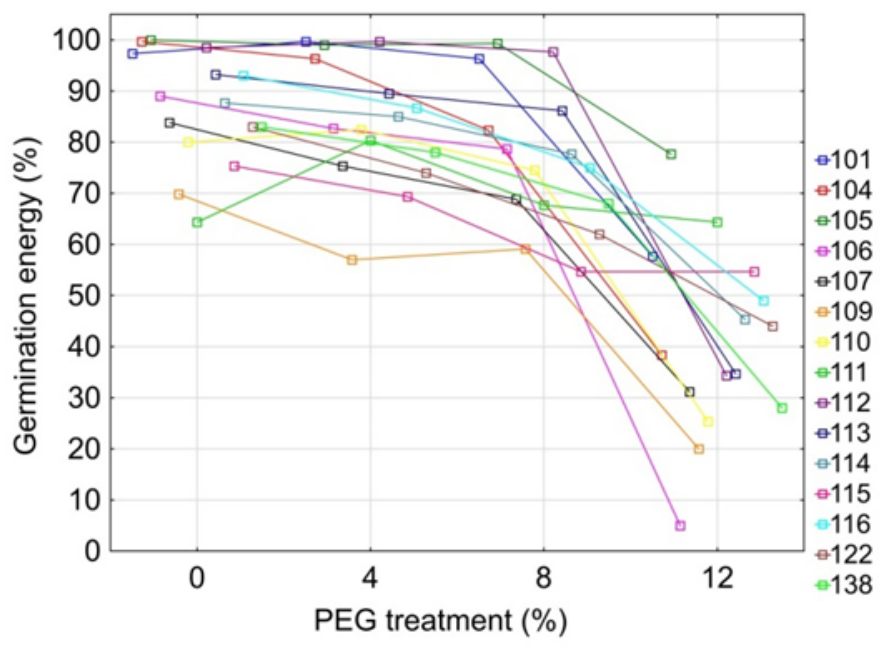

c)

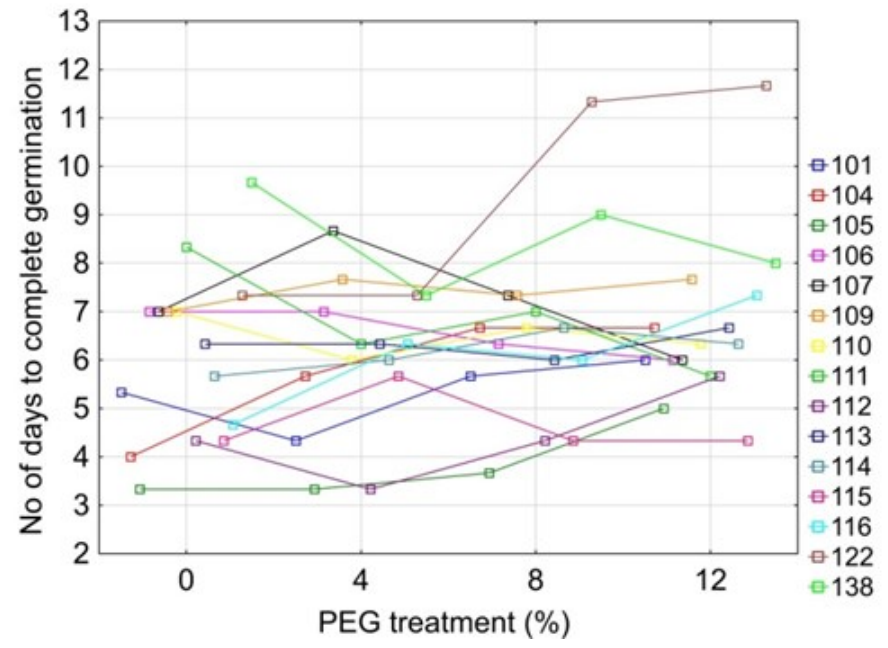

Figure 1. Germination percentage (a), germination energy (b) and number of days to complete germination (c) in tomato populations under the PEG treatments 
Table 1. Mean values and the corresponding ranks of germination percentage (GP, \%), germination energy (GE, \%), and number of days to complete germination (GD) in tomato populations; under the PEG treatments. The values related to the treatments are presented as percentages of the control $(100 \%)$

\begin{tabular}{lcccccccccccc}
\hline Population & $\mathrm{GP}_{0}$ & $\mathrm{GP}_{4}$ & $\mathrm{GP}_{8}$ & $\mathrm{GP}_{12}$ & $\mathrm{GE}_{0}$ & $\mathrm{GE}_{4}$ & $\mathrm{GE}_{8}$ & $\mathrm{GE}_{12}$ & $\mathrm{GD}_{0}$ & $\mathrm{GD}_{4}$ & $\mathrm{GD}_{8}$ & $\mathrm{GD}_{12}$ \\
\hline Mean & 90.5 & 96.1 & 90.6 & 53.3 & 86.5 & 96.9 & 88.3 & 47.6 & 6.1 & 102.9 & 110.1 & 114.4 \\
CV $(\%)$ & 10.2 & 6.5 & 8.7 & 38.0 & 12.5 & 9.7 & 10.7 & 47.6 & 29.5 & 20.9 & 20.8 & 26.8 \\
LSD $_{0.05}$ & 3.1 & 3.1 & 2.0 & 2.5 & 3.0 & 2.2 & 1.5 & 2.5 & 1.0 & 1.5 & 2.8 & 1.8 \\
LSD $_{0.01}$ & 4.1 & 4.2 & 2.7 & 3.3 & 4.1 & 2.9 & 2.0 & 3.3 & 1.3 & 2.0 & 3.7 & 2.4 \\
\hline Ranks & & & & & & & & & & & & \\
\hline G101 & 3 & 3 & 2 & 4 & 4 & 3 & 4 & 4 & 10 & 12 & 6 & 6 \\
G104 & 2 & 6 & 7 & 9 & 2 & 7 & 10 & 8 & 14 & 1 & 1 & 1 \\
G105 & 1 & 4 & 3 & 2 & 1 & 5 & 2 & 2 & 15 & 7 & 5 & 4 \\
G106 & 8 & 10 & 11 & 15 & 7 & 11 & 8 & 15 & 4 & 8 & 14 & 12 \\
G107 & 11 & 12 & 13 & 14 & 9 & 13 & 11 & 10 & 5 & 4 & 7 & 13 \\
G109 & 15 & 15 & 10 & 11 & 14 & 15 & 9 & 14 & 6 & 5 & 8 & 8 \\
G110 & 12 & 5 & 8 & 10 & 12 & 2 & 5 & 13 & 7 & 11 & 11 & 11 \\
G111 & 14 & 1 & 1 & 1 & 15 & 1 & 1 & 1 & 2 & 14 & 15 & 15 \\
G112 & 4 & 2 & 4 & 12 & 3 & 4 & 3 & 11 & 12 & 13 & 9 & 5 \\
G113 & 6 & 8 & 5 & 8 & 5 & 8 & 6 & 9 & 8 & 10 & 12 & 9 \\
G114 & 9 & 7 & 9 & 7 & 8 & 6 & 7 & 7 & 9 & 6 & 4 & 7 \\
G115 & 13 & 11 & 15 & 3 & 13 & 12 & 15 & 3 & 13 & 3 & 10 & 10 \\
G116 & 7 & 9 & 12 & 6 & 6 & 10 & 13 & 6 & 11 & 2 & 3 & 3 \\
G122 & 10 & 14 & 14 & 5 & 10 & 14 & 14 & 5 & 3 & 9 & 2 & 2 \\
G138 & 5 & 13 & 6 & 13 & 11 & 9 & 12 & 12 & 1 & 15 & 13 & 14 \\
\hline
\end{tabular}

Table 2. Spearman's coefficients of rank correlation among tomato germination percentage (GP) and energy (GE) observed in PEG treatments

\begin{tabular}{l|lllllll} 
& $\mathrm{GP}_{4}$ & $\mathrm{GP}_{8}$ & $\mathrm{GP}_{12}$ & $\mathrm{GE}_{0}$ & $\mathrm{GE}_{4}$ & $\mathrm{GE}_{8}$ & $\mathrm{GE}_{12}$ \\
\hline $\mathrm{GP}_{0}$ & 0.38 & 0.46 & 0.00 & $0.91^{* *}$ & 0.32 & 0.23 & 0.11 \\
$\mathrm{GP}_{4}$ & & $0.77^{* *}$ & 0.40 & 0.40 & $0.94^{* *}$ & $0.82^{* *}$ & 0.39 \\
$\mathrm{GP}_{8}$ & & 0.25 & 0.33 & $0.81^{* *}$ & $0.86^{* *}$ & 0.22 \\
$\mathrm{GP}_{12}$ & & & -0.01 & 0.34 & 0.20 & $0.93^{* *}$ \\
$\mathrm{GE}_{0}$ & & & & 0.25 & 0.26 & 0.10 \\
$\mathrm{GE}_{4}$ & & & & & & $0.80^{* *}$ & 0.29 \\
$\mathrm{GE}_{8}$ & & & & & & 0.13
\end{tabular}

As for the remaining two treatments, the response of the tomato populations to drought varied more in the $12 \%$ (CV 38.0 and $47.6 \%$ for germination percentage and energy, respectively) than in the $8 \%$ PEG; therefore the $12 \%$ concentration may be recommended for comparing tomato genotypes in terms of early-imposed drought tolerance. This is twice the concentration suggested for pepper (Demir \& Mavi 2008), which illustrates the importance of optimizing the treatments. Concerning the observed exponential shape of the treatment-trait curve, PEG concentration higher than $12 \%$ would probably exhibit extremely harmful effect on tomato germination and therefore should not be considered as useful for this type of research.

Rank correlation coefficients were calculated in order to investigate the interrelationships among the germination parameters (Table 2). There were no correlations between control and any of the imposed treatment, confirming that the differences among the populations were due to the response to PEG and not to the germination ability per se. Positive correlations were detected for germination percentage and energy in both control and the treatments, meaning that any of the two parameters may be informative for differentiating the populations for drought tolerance. The response of the analyzed populations to the 4 and 8\% PEG treatment also correlated. Taking into account the mentioned correlations and the fact that $12 \%$ PEG still had more pronounced effect on germination energy $(47.6 \%$ of the control) than on germination percentage $(53.3 \%$, Table 1$)$; the germination energy may be further considered as selection criterion for drought tolerance. 
a)

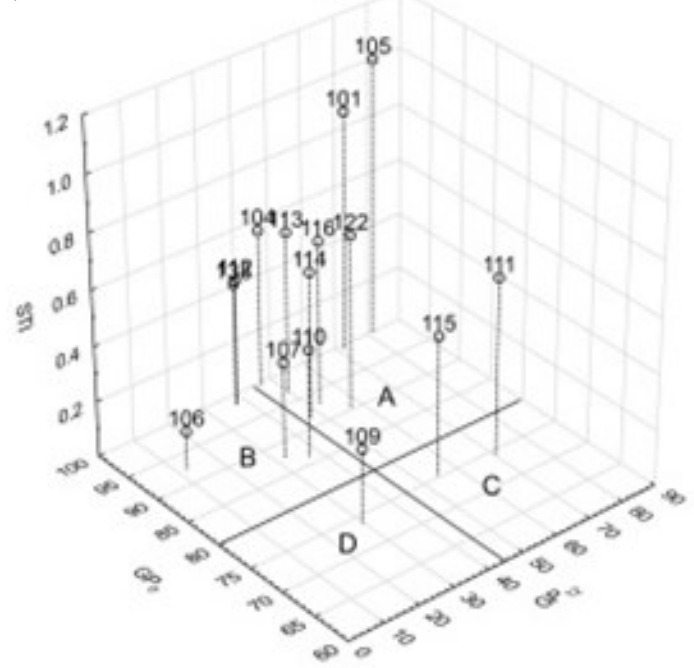

b)

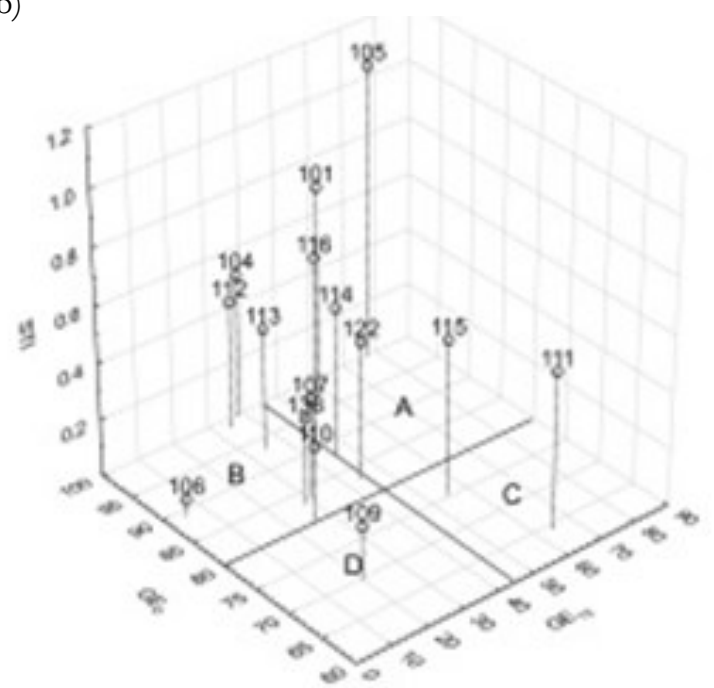

Figure 2. Stress tolerance index (STI) based on tomato germination percentage (a) and energy (b) under 12\% PEG treatment $\left(\mathrm{GE}_{12}\right)$ and control $\left(\mathrm{GE}_{0}\right)$

Drought stress selection indices are widely used statistical approach for differentiating genotypes of various agricultural plants on the basis of their tolerance to limited water supply. Among available indices that are based on plant's performance at the optimal and limited watering regime (e.g. Fischer \& Maurer 1978, Fischer \& Wood 1979, Moosavi et al. 2008, Farshadfar \& Javadinia 2011), the stress tolerance index (STI) proposed by Fernandez (1992) is the most frequently used (Anwar et al. 2011, Drikvand et al. 2012, Farshadfar et al. 2012, Brdar-Jokanović et al. 2014). The Fernandez's model means calculating the STI for each genotype and plotting it on three-dimensional graph, together with the genotypic performance under two watering regimes (Figure 2). This graphical display allows the differentiation of the analyzed tomatoes in four categories. Category A marks the genotypes with comparatively high germination percentage and/or energy at both optimal and drought conditions, therefore the tomatoes falling in it are the most desirable ones. Other categories distinguish the tomatoes with satisfactory performance at non-stress (B) or stress (C) conditions only, as well as the generally poor-performing genotypes (D).

Accordingly, the populations 105, 101, 116 and 114 with high germination percentage and energy in both stress and non-stress environments and the populations 111 and 115 with good performance in 12\% PEG treatment may be considered as tolerant to early imposed drought. The results are compared to the results of the experiments that included testing the same populations for drought tolerance at the stage of intensive vegetative growth. Sixteen drought stress selection indices and hierarchical cluster analysis were used in these studies to differentiate the populations (Zdravković et al. 2013, Brdar-Jokanović et al. 2014a, b). In accordance to the observations (Chaves et al. 2003, Foolad 2005, Shamim et al. 2014) that drought response of the particular tomato genotype often vary among the developmental stages, a majority of the populations designated as tolerant at germination stage belonged to the medium sensitive or sensitive $(111,114,115,116)$ group when assessed in the stage of vegetative growth. However, the population which had the highest value of STI (105) at germinated stage was also distinguished as tolerant to limited water supply in the vegetative phase of life cycle.

Therefore, the response of tomatoes to drought stress imposed at early stages does not necessarily imply the response in later phases of development. However; when it comes to breeding, a special attention should be paid on the genotypes exhibiting drought tolerance throughout more stages of development. In this sense, the 105 population would be the material of choice for breeding drought tolerant tomato.

\section{Conclusions}

The increasing $(4,8,12 \%)$ polyethylene glycol (PEG) treatments decreased the germination percentage and energy in the investigated tomato populations. Treatment effects on the number of days to complete germination were inconsistent and therefore statistically insignificant. The $12 \%$ PEG treatment is recommended as informative for comparing the tomatoes in terms of tolerance to early imposed drought stress. Germination energy is suggested as selection criterion. The populations $105,101,116,114,111$ and 115 are distinguished as drought tolerant; however, the tolerance at germination stage does not necessarily imply the tolerance in later stages of tomato life cycle. The population 105 is recommended for breeding drought tolerant varieties. 


\section{References}

Anwar, J., Subhani, G.M., Hussain, M., Ahmad, J., Hussain, M., \& Munir, M. (2011). Drought tolerance indices and their correlation with yield in exotic wheat genotypes. Pak. J. Bot., 43(3), 1527-1530.

Ashraf, M. (2010). Inducing drought tolerance in plants: Recent advances. Biotechnol. Adv., 28, 169-183. doi:10.1016/ j.biotechadv.2009.11.005

AQUASTAT (2015). AQUASTAT database. Retrieved from http://fao.org/nr/aquastat

Brdar-Jokanović, M., Pavlović, S., Girek, Z., Ugrinović, M., \& Zdravković, J. (2014a): Assessing tomato drought tolerance based on selection indices. Ratar. Pourt., 51(1), 38-45. doi: $10.5937 /$ ratpov $51-5887$

Brdar-Jokanović, M., Girek, Z., Pavlović, S., Ugrinović, M., \& Zdravković, J. (2014b): Shoot and root dry weight in drought exposed tomato populations. Genetika, 46(2), 495-504. doi: 10.2298/GENSR1402495B

Chaves, M.M., Maroco, J.P., \& Pereira, J.S. (2003). Understanding plant responses to drought - from genes to the whole plant. Funct. Plant Biol., 30(3), 239-264. doi:10.1071/FP02076

Demir, I., \& Mavi, K. (2008). Effect of salt and osmotic stresses on the germination of pepper seeds of different maturation stages. Braz: Arch. Biol. Technol., 51(5), 897-902.

Drikvand, R., Doosty, B., \& Hosseinpour, T. (2012). Response of rainfed wheat genotypes to drought stress using drought tolerance indices. Journal of Agricultural Science, 4(7), 126-131. doi: $10.5539 /$ jas.v4n7p126

FAO (2015). FAOSTAT database. Retrieved from http:// faosta.fao.org

Farshadfar, E., \& Javadinia, J. (2011). Evaluation of chickpea (Cicer arietinum L.) genotypes for drought tolerance. Seed and Plant Improvement Journal, 27(4), 517-537 (in Persian).

Farshadfar, E., Jamshidi, B., \& Aghaee, M. (2012a). Biplot analysis of drought tolerance indicators in bread wheat landraces of Iran. International Journal of Agriculture and Crop Sciences, 4(5), 226-233.

Fernandez, G.C.J. (1992). Effective selection criteria for assessing plant stress tolerance. In: Adaptation of food crops to temperature and water stress, (Ed.) Kuo, C.G., Shanhua: Asian Vegetable Research and Development Center, Taiwan, Publ. No. 93410, 257-270.

Fischer, R.A., \& Maurer, R. (1978). Drought resistance in spring wheat cultivars: I. Grain yield response. Aust. J. Agric. Res., 29 (5), 897-912. doi:10.1071/AR9780897

Fischer, R.A., \& Wood, J.T. (1979). Drought resistance in spring wheat cultivars: III. Yield association with morphophysiological traits. Aust. J. Agric. Res., 30(6), 1001-1020.
doi:10.1071/AR9791001

Foolad, M.R. (2005). Breeding for abiotic stress tolerances in tomato. In: Abiotic stresses: plant resistance through breeding and molecular approaches, (Eds.) Ashraf, M., Harris, P.J.C., The Haworth Press, New York, USA, 613-684.

Foolad, M.R. (2007). Current status of breeding tomatoes for salt and drought tolerance. In: Advances in molecular breeding toward drought and salt tolerant crops, (Eds.) Jenks, M.A., Hasegawa, P.M., Mohan Jain, S., Springer, Dordrecht, Netherlands, 669700

George, S., Jatoi, S.A., \& Siddiqui, S.A. (2013). Genotypic differences against PEG simulated drought stress in tomato. Pak. J. Bot., 45(5), 1551-1556.

Ghebremariam, K.M., Liang, Y., Li, C., Li, Y., \& Qin, L. (2013). Screening of tomato inbred-lines for drought tolerance at germination and seedling stage. Journal of Agricultural Science, 5 (11), 93-101. doi:10.5539/jas.v5n11p93

Michel, B.E., \& Kaufmann, M.R. (1973). The Osmotic Potential of Polyethylene Glycol 6000. Plant Physiology, 51, 914-916.

Moosavi, S.S., Yazdi Samadi, B., Naghavi, M.R, Zali, A.A, Dashti, H., Pourshahbazi, A. (2008). Introduction of new indices to identify relative drought tolerance and resistance in wheat genotypes. Desert, 12, 165-178.

Ragab, A.R., Abdel-Raheem, A.T., Kasem, Z.A., Omar, F.D., \& Samera, A.M. (2007). Evaluation of R1 tomato somaclone plants selected under poly ethylene glycol (PEG) treatments. 8th African Crop Science Society Conference Proceedings, Vol. 8, 27-31 October 2007, El-Minia, Egypt, pp. 2017-2025.

RZS (2015). Statistical office of the Republic of Serbia database. Retrieved from http://stat.gov.rs

Shamim, F., Farooq, K., \& Waheed, A. (2014). Effect of different water regimes on biometric traits of some tolerant and sensitive tomato genotypes. J. Anim. Plant Sci., 24(4), 1178-1182.

Statistical office of the Republic of Serbia (2012). Statistical yearbook of the Republic of Serbia. Statistical office of the Republic of Serbia, Belgrade, p. 410.

Statistical office of the Republic of Serbia (2013). Statistical yearbook of the Republic of Serbia. Statistical office of the Republic of Serbia, Belgrade, p. 420.

Takač, A., Gvozdenović, Đ., Bugarski, D., \& Červenski, J. (2007). Savremena proizvodnja paradajza. Zbornik radova Instituta za ratarstvo i pourtarstvo, 43(1), 269-281.

Zdravković, J., Pavlović, N., Girek, Z., Zdravković, M., \& Cvikić, D. (2010). Characteristics important for organic breeding of vegetable crops. Genetika, 42(2), 223-233. doi: 10.2298/ GENSR1002223Z

Zdravković, J., Jovanović, Z., Đorđević, M., Girek, Z., Zdravković, M., \& Stikić R. (2013). Application of stress susceptibility index for drought tolerance screening of tomato populations. Genetika, 45(3), 679-689. doi: 10.2298/GENSR1303679Z

\section{Klijanje paradajza u uslovima sušnog stresa izazvanog PEG-om}

\section{Milka Brdar Jokanović · Jasmina Zdravković}

Sažetak: Cilj ovog istraživanja je bila procena efekata sušnog stresa na klijavost, energiju klijanja i broj dana do završetka klijanja kod petnaest populacija paradajza; utvrđivanje tretmana koji je najpogodniji za klasifikaciju paradajza na osnovu tolerantnosti na sušu u ranim fazama životnog ciklusa; kao i identifikacija populacija koje bi mogle biti iskorišćene za oplemenjivanje. Ogled je podrazumevao kontrolu (klijanje u prisustvu destilovane vode) i rastuće (4, 8 i 12\%, w/v) tretmane polietilen-glikolom (PEG). Klijavost i energija klijanja su bili značajno niži u prisustvu PEG-a. Razlike u klijanju među populacijama paradajza su bile najizraženije kod tretmana $12 \%$ PEG, stoga se ovaj tretman preporučuje za dalji rad. Međutim, tolerantnost paradajza na sušu u fazi klijanja nije obavezno indikator tolerantnosti na ograničenu obezbeđenost vodom u kasnijim fazama razvoja biljke. Populacija 105 bi se mogla iskoristiti za oplemenjivanje paradajza tolerantnog na sušu.

Ključne reči: klijanje, Lycopersicon esculentum Mill., paradajz, polietilen-glikol, tolerantnost na sušu 